\title{
RELATIONSHIP BETWEEN COMPANIES ON B2B FIELD IN ROMANIA AND THEIR SUPPLIERS. A STRATEGIC MARKETING MANAGEMENT APPROACH
}

Cãescu Ștefan CLAUDIU The Academy of Economic Studies, Romania

\begin{abstract}
The main objective of this paper is to identify a conceptual model to integrate the strategic marketing management instruments in the relationship between the organization on the business to business market in Romania and its suppliers. In order to be able to see the way in which the conceptual model of integration of strategic marketing in the relationship with suppliers can be applied by Romanian companies on B2B field, a quantitative research has been undertaken, having as main objectives to identify which are the main criteria used by organizations in segmenting, targeting and positioning their suppliers and also to identify what type of relationship exists between companies in the B2B field in Romania and their main suppliers. The whole marketing theory resides on the idea of customer and market orientation, and starting from this the concept organizations are as successful as much as they adapt their reactions to the evolutions and changes in the marketing environment. As a consequence to this the marketing theory developed by placing in the center of its scientific methodology and instruments the market and the relationship of the company with its customers. The scientific research presented throughout this paper approaches this theory for business to business field. Our research, has led us to the conclusion that, especially on business to business markets, organizations focus their marketing activities not only on the relationship with their customers, but on the relationship with their suppliers as well. In the supply chain, companies appear as buyers and also as clients for the suppliers of goods, financial resources and of work force. The classical model that describes the relationship of a company with its suppliers presents the acquiring company as a "passive" one, the "active" role being the one of the supplier for which the buying organization appears like customer. Although in numerous occasions the buying company has an "active" role, thus being able to discuss about a different strategic approach (an active one).
\end{abstract}

\section{INTRODUCTION}

This paper is based on the idea of distinct consideration, in terms of strategic marketing, of the relationship between the organization on the business to business market and its suppliers. The organization on the business to business market is developing, implementing, leading and coordinating marketing processes both downstream and upstream, in relation with its customers and suppliers (Olteanu, 2003:96) (Exhibit 1).

Figure 1.The integration of the marketing process of the organization on the business to business market in the relationship with its suppliers and customers

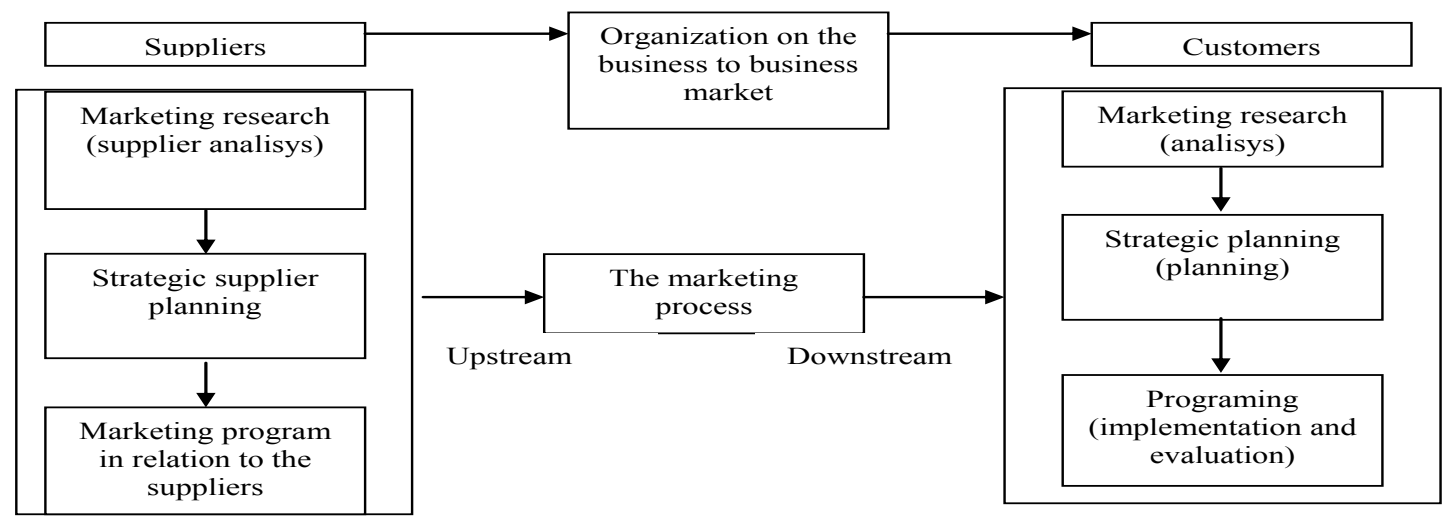


The entire marketing theory resides on the concepts of environment and market, this being defined as the optics, the philosophy according to which organizations are successful as they are adapting their actions to the evolution and dynamics of the environment (Florescu, 1992:24). Consequently, theory developed through placing market issues and the relationship the company has with the market in the center of the scientific marketing tools (Olteanu, 2003). Our studies and researches have lead to the conclusion that especially in the case of business to business markets, companies are paying more attention not only to the sales but also to acquisition market. It is important to mention that companies are present on the supply market both as buyer and as customer of the suppliers of goods and services, financial resources and labor force. According to the classical model of the relationship management with the suppliers, the purchasing company is in a "passive" posture, while the "active" role is that of the suppliers for which the purchaser is the customer. However, in many cases, the company assumes an "active" role and we can also consider another strategic alternative policy (an active one). By placing providers in a position of "customers", the company conducts a thorough research on them in order to better know them, and then does supplier selection on this information, in order to define an appropriate policy expressed through similar objectives and strategies, up to the point to those used on trading markets. As already mentioned, in all cases the supply demand appears as "derived" demand (Tull\&Kahle, 1990:224), so it depends on the demand of the own customers. Consequently, the marketing policy developed in the relationship with the suppliers is dependent on the trading policy and can be conceptually placed within the supply chain management area.

Starting from this approach the B2B organization does marketing research of suppliers (Ketchen et al, 2007: 455-458; Lee and Grewal, 2004: 157-171) (suppliers as a part of the microenvironment and SWOT analyses of suppliers), based on which defines its strategic approach on suppliers (Bowersox et al, 2002) (segmenting, targeting, positioning and portfolio analyses of suppliers), followed by the implementation of a marketing mix relative to suppliers (Hutt \& Spech, 2004:312)(Figure 2).

Figure 2. The stages of the marketing process in the relationship with suppliers

\begin{tabular}{|c|c|c|}
\hline $\begin{array}{l}\text { Marketing research } \\
\text { Supplier analysis } \\
\text { microenvironment } \\
\text { component } \\
\text { SWOT supplier } \\
\text { analysis }\end{array}$ & $\begin{array}{c}\begin{array}{c}\text { Strategic supplier } \\
\text { planning }\end{array} \\
\text { Supplier segmentation } \\
\text { Supplier targeting } \\
\text { Supplier positioning } \\
\text { Supplier portfolio } \\
\text { analysis }\end{array}$ & $\begin{array}{c}\begin{array}{c}\text { Programming } \\
\text { (implementation and } \\
\text { evaluation) }\end{array} \\
\text { Product policy in the } \\
\text { relationship with suppliers } \\
\text { Price policy in the } \\
\text { relationship with suppliers } \\
\text { Distribution policy in the } \\
\text { relationship with suppliers } \\
\text { Promotional policy in the } \\
\text { relationship with suppliers }\end{array}$ \\
\hline
\end{tabular}

In order to be able to see the way in which the conceptual model of integration of strategic marketing in the relationship with suppliers can be applied by Romanian companies on B2B field, a quantitative research has been undertaken, having as main objectives to identify which are the main criteria used by organizations in segmenting, targeting and positioning their suppliers and also to identify what type of relationship exists between companies in the B2B field in Romania and their main suppliers.

\section{RESEARCH METHODOLOGY}

In Romania, the use of strategic marketing as a core element in the relationship with suppliers by companies on the business to business market is still in its early stages, in some cases even at the "unconscious" level. In order to develop the practice, it takes a well proven theory that must also be adapted to the current demands of the domain of business relationship with suppliers. Thus, it appears that there is a need for information about the current status of strategic marketing implementation by the companies on the Romanian business to business market in the relationship with their suppliers 
and, especially, identifying the ways in which organizations use these techniques and instruments to develop their relationships with suppliers.

Starting from the issue presented in the previous stage, this research aims to analyze how organizations operating on the Romanian business to business market use strategic marketing in order to develop their relationships with their suppliers. The research also has a secondary purpose, namely to see if there are identifiable elements of relationship marketing in the relationships that companies on the B2B market are developing with their suppliers.

The objectives of the research are:

a) Identifying the most important criteria used in supplier evaluations

b) Identifying the most important elements used in supplier selection

c) Identifying the relationship between the company on the B2B market and its main supplier

d) Identifying the ways of the relationships between the company on the B2B market and its suppliers are conducted

e) Identifying the degree of supplier information knowledge

f) Identifying the way of use of the marketing mix in the relationships with suppliers

g) Indentifying the objectives targeted through the supply process

The researched collectivity is represented by the companies operating in Romania on the B2B urban market (cities with over 50,000 inhabitants), either domestic or foreign, in any field of activity. In order to meet the pre-established objectives of this research there were a series of variables pursued for each organization. These variables are defined both conceptually and operationally. In order to measure as exactly as possible the phenomena within this research, both metric and non-metric scales were used (Catoiu, 2002:278). The personal "face to face" survey was used as an information gathering method for this research and the instrument used was the questionnaire. In order to determine the sample to conduct the research on, the decision was no to use a random sampling method, as the issue studied is a new element in the Romanian marketing research, that is why it was regarded as an exploratory research, that will make available information necessary to a future design of a research on a representative sample. There were in total 60 interviews with companies present on the B2B field in Romania.

\section{RESULTS}

The questionnaire consisted of four sections. The first section assesses the main criteria used by companies to evaluate suppliers in order to identify the underlying elements that are the basis of the purchasing centre decisions. The second section presents the companies' perspective on the main criteria considered for supplier selection aimed at identifying the elements that are the basis of the supplier selection, segmentation, and targeting processes. The third and fourth section of the questionnaire are presenting the mirror view of the opinion the company has on their main supplier and the attitude towards them in order to identify how strategic planning elements are used in the relationship with the supplier, particularly the product and price policies. The behavior towards the main supplier was chosen to be analyzed in order to see better the attitude towards establishing long term relationships. This research was also aimed at highlighting the correlation relationships between the different research variables.

With regards to the main criteria used to evaluate suppliers that were considered in supplier management by the companies on the business to business market in Romania, these are in the order of their importance (Figure 3): the quality of the supplied products, the price of the products, the payment facilities and discounts offered by the suppliers. These results are proving that although the most important aspect considered is the quality, then all of the others are connected to the price, meaning that although the Romanian companies are seeking high quality products, they cannot afford them and aim to purchase at the lowest cost possible and on credit terms.

It is noted that, although internationally companies on the B2B market are considering the most important attribute in supplier evaluation the product availability, on the Romanian market this attribute is the fifth ranked in order of its importance. This proves that the supply chain is not very well established and the companies are using large inventories of input products instead of JIT systems that would allow them to solve more efficiently the other issues connected to their liquidity (large invento- 
ries of input products $->$ financial assets $->$ low liquidity $->$ sought advantages connected to price, discounts, and payment methods). Noteworthy is also the fact that when analyzing the questionnaires for the most important four criteria, the answer that was most frequently selected was "total agreement". The low score obtained by the additional services offered by the supplier represents the willingness of the companies to waive certain additional services solely to obtain a lower price for the supplied product. However, this statement reflects a simplistic thinking from companies on the business to business market in Romania that are regarding the supply cost solely from the point of view of the basic price of supplied product and not from the point of view of the integrated logistics costs that also contains the additional services offered and may generate economies of scale on the whole. A low importance is given also to the novelty of the product purchased, which is understandable considering that a new product is usually associated with a higher price and possibly questionable reliability. One can also note that the least important criteria in supplier evaluation is the method of promoting the product offered, and this only re-confirms the minor role played by the promotional techniques such as advertising or sales promotions on the B2B market (Hellman ,2005:4-11).

Figure 3. Criteria used in supplier evaluation

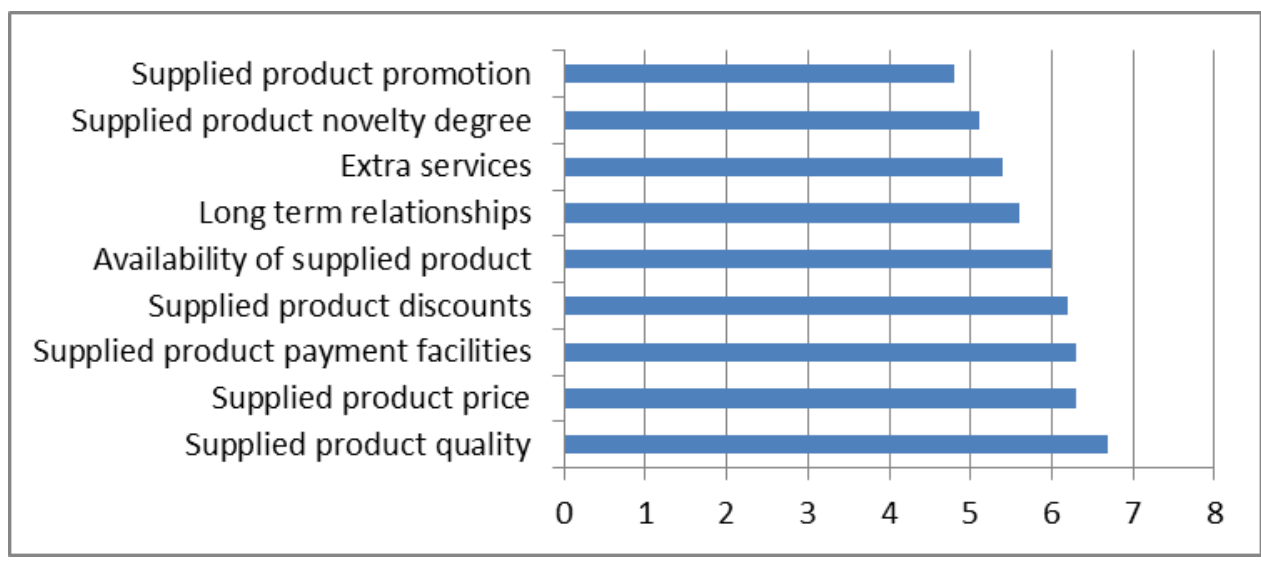

When evaluating the most important elements considered in supplier selection, the first one is the "supplier reliability, business references", this proving the desire companies have to establish long term partnership relationships with their suppliers (Figure 4). Nevertheless, correlating this characteristic with the importance of the long term relationships in the supplier, evaluation that received only a mediocre score in the first section of the questionnaire we can state that the desire to evaluate suppliers firstly on their reliability denotes primarily a certain convenience.

Figure 4. Criteria used in supplier selection

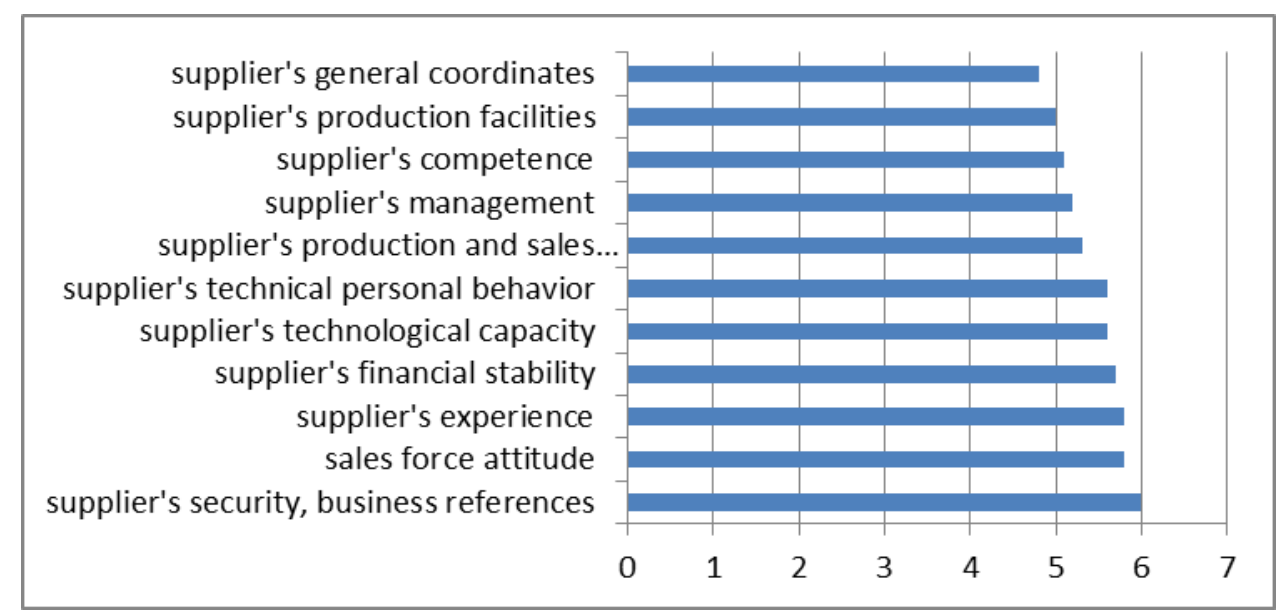

It is also noted that the supplier's production facilities are proving to be the least important in the supplier selection process, which shows that although quality is the most important attribute in supplier evaluation, it is not estimated on objective criteria. The fact that the production and sale equipment were inferiorly ranked also supports this affirmation. When continuing to analyze the results from this section we can note that organizations do not value greatly the human resources of the suppliers, this 
being proved by the low scores obtained by the supplier's staff, management and even technical personnel. After analyzing the responses in terms of their frequency it has been observed that for the first five criteria considered the response that occurred most frequently is that of "partial agreement".

Analyzing the third section of the questionnaire, where companies on the B2B market are expressing their opinions on their main suppliers, one can note that these companies are considering the relationship with the main suppliers as being a partnership one. Generally, they consider that suppliers are reliable, trying to fulfill their obligations and negotiating fairly in most of the cases, being truthful, a real partner for discussion and not trying to deceive. Also to be noted is that although the responses in this section indicate a strong partnership relationship, the companies on the $\mathrm{B} 2 \mathrm{~B}$ market do not consider as very important to develop partnerships when suppliers are evaluated.

Turning to the last section of the questionnaire, we can note that the highest grade is given to a statement that also reveals the partnership relation between the two companies, namely that there is an information exchange between the two entities. However, it should be noted further that although there is a certain openness towards exchange of information between parties, this does not apply when it comes to confidential information or even access to patents or inventions, although these may be useful to the supply chain. Regarding supplier assessment, this section repeats what has been presented in the first section, the fact that the quality is very important and there is a need for the supplier to be quality certified. The performance of a supplier is not simply evaluated in terms of production costs but using several evaluation criteria. It should be noted that there is collaboration between the two parties in terms o reducing production costs. Although there is a partnership relation, the two parties also have a collaboration contract that, in most of the cases has a "gentlemen's agreement" framework, to establish the relation between the parties in the supply chain.

In conclusion, the order of importance of the criteria used by the companies on the B2B market in Romania is: "quality of product", "price of product", "payment facilities", "discounts", "product availability", "long term relationships" and "services offered by the supplier". When comparing these with the theory that places first the product availability, then quality, price, services offered and the long term relationships, we can state that for Romanian companies the purchasing decision is mainly made on quality and price criteria. It is surprising that although the other characteristics that are related to price are considered important, product availability that generally equates to liquidity is not considered important.

Regarding the factors taken into consideration in the selection, segmentation and targeting of suppliers, the first one is the "reliability of the supplier company", then "the attitude of the sales staff", "the experience of the supplier" and "their economic stability". The criteria generally chosen were connected to the safety of the relationship with the supplier, emphasizing the interest towards developing partnership relationships. With regards to the opinion and attitude of the companies on the B2B market towards their main supplier, one can note a relationship of duality, as the supplier is considered to be seriously involved in the relationship and this is also the attitude of the company. There is also some skepticism in the relationship with the supplier, as the contract is considered very important, there is no exchange of confidential information and generally the supplier is not supported in terms of quality issues, although these may alter the company's offer also. On the product policy, the focus is on the quality of the product, and less on its novelty as companies prefer the safety of the known product. The supplier is also involved in the development of new products. With regards to the pricing policy, one can note the emphasis on its importance, and that of discounts and payment facilities obtained. The negotiation process is also very important, although there is a certain pressure from the main suppliers that tries to "have the last word".

Considering the results of the research, we can state that the relationships between the Romanian companies and their suppliers are still in their early stages of strategic marketing application, and the price is generally the core of the decisions made along the supply chain.

\section{MANAGERIAL IMPLICATIONS}

Based on the information obtained through the research conducted, we intend to continue identifying on conceptual level the way in which the segmentation, targeting and positioning, the portfolio analysis, and the marketing mix are developed in the relationship with the suppliers. 


\section{Supplier Segmentation, Targeting, and Positioning}

When applying segmentation as a strategic marketing tool used to identify the segments of suppliers, it is recommended to use the following criteria (Rangan \& Shapiro, 1995:96; Dibb \& Wensley, 2002:231-251): criteria regarding the supplying company that contain variables such as: general company coordinates, company staff and management, supplier experience, available production facilities; criteria for long term company vision with the following variables: financial aspects, economic performance and financial stability, organizational strategy and culture, technological aspects, supplier reliability, business references; criteria regarding the supplier business behavior with the following variables: the attitude of the sales staff, production and sales available equipment, the quality and availability of the products offered, the behavior of the technical staff, the management competence.

Targeting suppliers assumes the development of the marketing mix for one or several segments of suppliers, identified as a follow up of the segmentation. Two very important factors must be considered when a target segment of suppliers is chosen by one company or another: the attractiveness of that segment of suppliers and the compatibility between that segment and the company purchasing objectives, strategies and resources. The attractiveness of the segment of suppliers may be evaluated through one of the following aspects: size of the segment (number of potential suppliers); growth rate of the segment; competition on the segment, the greater the competition, the better conditions can the company obtain for the purchase; loyalty manifested by the supplier segment towards the company; expected profit margins. The compatibility is the result of the extent to which the suppliers from that segment are able to satisfy the company expectations on the business to business market with regards to (Webster, 1991:113): product availability, product quality, product price, services offered, and the availability of a partnership relationship. Based on the two elements there are the following strategic alternative of targeting a certain supplier segment: non-differentiated strategy of targeting all the segments of potential suppliers; differentiated strategy of focusing on two or more segments (the optimal alternative would be with two segments with a sharing ratio of 60/40); concentrated strategy when the company on the business to business market is focused on a single segment of suppliers. In order to analyze the suppliers to be targeted the company may also use the ABC (Parreto) method. This allows suppliers to be classified in three categories: "A" high importance ("strategic") suppliers, holding an important share in providing the organization with resources; usually, the A type suppliers hold 60$70 \%$ of the total volume of resources inputs and represent $20-30 \%$ out of the total number of suppliers; "B" medium importance suppliers, holding a relatively reduced share in ensuring the resources for the organization; usually the B type suppliers hold $20-30 \%$ out of the total volume of resource inputs and represent $40-50 \%$ from the total of suppliers; "C" low importance suppliers, with a low share in ensuring resources for the organization; usually the $C$ type suppliers hold approximately $10 \%$ out of the total input level and represent roughly $30-40 \%$ out of the total suppliers.

The positioning of the suppliers towards the company using the "perceptions map" supposes the succession of two stages: identification of the main features required by the company from potential suppliers (product availability, product quality, price, services offered, etc.) and the intensity of each of these characteristics for each particular supplier. Based on the two variables we can draw up a "perceptions map" for every supplier (Noir, 1977; Bobin, 1988; Kotler and Armstrong 2005) that would be the basis of the purchasing decision made by the company. The positioning of the company towards potential suppliers also assumes two stages: for the company to identify the main advantages sought by the supplier in the partnership relation and their importance; maximizing the position, which is trying to reduce the gap between the position of the company and the provider's expectations.

\section{The Analysis of the Supplier Portfolio}

As previously presented, the tools used in portfolio analysis of the products offered on the business to business market are focused on the market attractiveness, product competitiveness and also the life cycle of the product and of the market itself. These include a series of known methods such as the product life cycle method, the Boston Consulting Group method, the General Electric matrix or the Arthur D. Little matrix (Caescu\&Ionescu, 2008: 58-64). Using portfolio analysis as a tool for managing the supplier base will require the tracking of the following two indicators: the attractiveness of the supplier to be evaluated through the importance of the supplied product for the company's manufacturing process (the importance of the supplied product will be evaluated on a scale from 1 to 10); the competitiveness of the supplier will be assessed through the company specific purchasing variables: 
product availability, product quality, product price, additional services offered with the product and the possibility of developing a long term relationship with the company.

Based on these elements and using the known Boston Consulting Group growth-share matrix we can establish a similar one for the supplier analysis. The adapted form of this matrix is the following:

- "stars" are the suppliers that have high attractiveness and high competiveness. These are a main supply source for the company. The strategic objective is to "harvest" the profits based on the economies of scale that may be achieved through the purchasing process.

- "stones" are the suppliers that have low attractiveness and low competiveness. These are a back-up solution if the company even faces issues with stocked items. The strategic objective of the company is to reduce investments with these suppliers.

- "question marks" are the suppliers with high attractiveness and low competitiveness. The relationships with these suppliers must be developed as they constitute the main supply alternatives for high importance products in the company manufacturing process.

- "cash cows" are the suppliers with an important market position that do not supply important products for the company's purchasing process. They may represent sources of saving due to their strong market position and specialization in the manufacturing products or performing services.

For the products supplied by the "cash cows" and "stars" the companies may also chose to produce internally, considering the importance the supplied products are holding in the purchasing process of the company.

The value of the method suggested for the portfolio analysis is proven by the following aspects: the supplier portfolio analysis model allows the supplier base within the portfolio to be harmonized and identifies the suppliers that hold an important share in the company purchasing process; the model allows the analysis of the supplier base through the identification of the suppliers that may be considered value and economies of scale generators for the company purchasing process; as the accent is on the supplier's competitiveness and on the importance the supplied product holds in the purchasing process, the model of supplier portfolio analysis requires the organization to build an balanced portfolio that would allow the necessary products to be supplied in the necessary conditions in order for the company's product and services to generate profit (Porter, 2001:67);

\section{The Marketing Mix in the Relationship with Suppliers}

The product policy in the relationship with the suppliers involves several aspects such as:

1. Researching for new products from new supplier categories based on the type of the purchase, repeat purchase, modified or new purchase. As shown in one of the earlier chapters, the main products purchased on the B2B market within the acquisition process may be: "heavy" equipment (investment property), "light" ("auxiliary") equipment, raw materials, parts and consumables. Besides these material goods, the companies active on the manufacturing market are also involved in the trade of services for the manufacturing. Their role is very important for the activity of any company and most often contributes to the improvement of the offer and to the creation of a "solution" that the company then offers to its customers (Anghel\&Petrescu, 2001:15).

2. Identifying the products that meet the qualitative level the purchasing centre of the company is seeking and the collaboration with suppliers in order to ensure the demanded qualitative level. The strategies applied in the relationship with the suppliers may be: qualitative adaptation of the merchandise to the purchasing centre demand; qualitative differentiation based on the characteristics of the products to be manufactured; the qualitative consistency when large purchased volumes are involved and the qualitative consistency for the purchasing process that are very important.

3. The service and warranty policy offered by suppliers for the products that are purchased and will be incorporated in the final product offered to the final customer. Considering that a main characteristic of the products on the business market is the complexity of the products this assumes that there are a large number of components involved and ensuring service and warranty is very important to be offered by suppliers. In fact, the service and warranty policy of the company is a "sum" of the service and warranty services offered by its suppliers.

4. Launching new products on the market assumes that the company on the B2B market establishes new relations with the current supplier or identifies new suppliers and also purchases new products 
that undergo the same stages as when new products are launched on the market: establishing the launching period, the targeted area, the supply channels, preparing the purchasing centre, choosing the methods of supply;

The pricing policy in the relationship with supplier supposes the following aspects:

1. Establishing the final price of the product offered on the market as it depends greatly on the price of the products supplied. Generally the price is established based on three elements: costs, competition and demand. Establishing the price based on the costs involves considering the purchasing cost of the products supplied. When the company on the organizational market purchases high volumes from a sole supplier it can also impose certain price policy elements on the supplier: maintaining the price for a certain period of time, maximum level of prices, maximum cost for certain costing elements.

2. With regards to the pricing policy in the relationship with suppliers, the discount policy is very important, based on the quantities supplied, the products purchased and the payment methods applied. If on the consumer goods market the customer usually pays for the price displayed on the shelves and usually on the spot (cash, card, check), on the business market there are true pricing policies with regards to the supply of products. These are involving discounts offered based on the quantities ordered, based on the size of the order and on the payment condition (on the spot or forward).

The distribution policy in the relationship with suppliers involves all the elements of development of the distribution channels downstream from the company on the business to business market (supply channels). This is the most important marketing mix component in the relationship with the suppliers. Thus, here we can consider:

1. The dimensions of the supply channel with its three components: the length of the channel depends on the number of intermediate levels used in supplying the products or services; the width of the channel regards the number of supplier used on a certain level and selected to supply a certain product; the depth of the channel reflects the proximity between the supplier and the purchasing company. Based on the volume of the purchase, there are certain production or storage facilities that may be developed even within the purchasing company.

2. The types of supply channels used. If the company purchases from the local or international (import) market it may act or not through intermediaries in order to ease its purchasing process. Thus, we can have direct, short or long distribution channels.

3. The type of intermediaries used. They can be whole-sale storages, trading houses, brokers or export agents of the manufacturer.

4. Strategic alternatives considered. Based on the number of suppliers used the company may opt for an extensive supply (large number of suppliers), a selective supply (reduced number of suppliers, usually two, with the share of 60/40), or an exclusive supply when only one supplier is used.

The promotional policy reflects the communication flow between the supplier and the purchasing company and how the company is positioned to communicate with the supplier, how the use of the procurement center communicates to the supplying company. The purchasing center of the B2B company is the main element of communication with the supplying company. It is very important that they "sell" the company as a reliable partner for the supplying company. There are promotional techniques that can be used in the relationship with suppliers also, for example sales promotional techniques. The purchasing company may offer bonuses to its supplier (as payment for higher prices or payment in advance) if the latter succeeds to meet unscheduled needs of the company on the business to business market.

\section{ORIGINALITY}

The presented research, considering the usage of the strategic marketing management instruments on the relationship between companies and their suppliers is the first one of its kind. The study can represent a first step in developing, testing and validating a model of strategic marketing management integration in the relationship between companies on $\mathrm{B} 2 \mathrm{~B}$ field and their suppliers.

Performing the SWOT analyses for evaluating and selecting the suppliers of a company in the B2B field means: identifying the strengths, weaknesses, opportunities, and threats for each supplier individually (Palmer, 2002: 135 - 143). Portfolio analyses of suppliers, helps the company identify which of its suppliers are most important in the acquisition process (Caescu and Ionescu 2008: 58-64). The 
model of portfolio analyses of suppliers permits analyzing a database of suppliers, to see which of them generate added value and scale economies $\mathrm{n}$ the company's acquisition process. Because it focuses on the suppliers competitiveness and on the importance of the supplied product, the portfolio analyses model of suppliers, forces the organization to put together a well-balanced base of suppliers which will allow the company to ensure for itself the necessary products, within the specified parameters thus obtaining finished products that will generate higher profits (Porter,2001:67).In B2B markets a segmentation of suppliers can be done by considering which is, the most important criteria taken into consideration when an acquisition is made (Dibb and Wensley, 2002:231-251). A company generally acquires in the importance order based on: product availability, quality, price, services offered and possibility of long term relations (Laiderman, 2005: 64-75). In using segmentation as a strategic marketing method for identifying potential suppliers the following criteria are recommended (Rangan and Shapiro, 1995:96; Taylor, 2003): organizational criteria regarding the supplying company, its long term vision and regarding its business behavior. Targeting of suppliers means developing the marketing mix for one or more of the segments identified based on the segmentation process. Two main factors are to be considered when a segment of suppliers is targeted by a company: the attractiveness of the segment of suppliers and the compatibility of the segment with the acquisition objectives, strategies and resources of the company (Webster, 1991:113). Positioning suppliers by using the perception map (Noir, 1977; Bobin, 1988; Kotler and Armstrong 2005) means following two steps: which are the main characteristics of the supplied products and the intensity of each one of this characteristics for every supplier. Last, but not the least elaborating strategic planning in relationship with suppliers, means also applying the main components of the marketing mix: product, price, placement and promotion.

\section{ACKNOLEDGEMENTS}

This work was co-financed from the European Social Fund through Sectorial Operational Programme Human Resources Development 2007-2013, project number POSDRU/1.5/S/59184 "Performance and excellence in postdoctoral research in Romanian economics science domain". 


\section{REFERENCES}

Anghel L. D. and Petrescu E. C.,(2001), Business to Business Marketing, Uranus PH, Bucharest, Romania

Bobin, J. P., (1988), Le marketing politique, Milan Midia PH, Paris, France

Bowersox J. D., Closs J. D., Cooper M. B., (2002), Supply chain logistics management, McGrawHill $\mathrm{PH}$, New York,USA

Cãescu Șt.C.and Ionescu F., (2008), Managementul portofoliului de produse element de baza in planificarea strategica - Metoda Boston Consulting Group (The management of the products portfolio as a basic element in strategic planning - the Boston Consulting Group method), Marketing On-line Magazine, $1^{\text {st }}$ volume, 2008, pp.58-64

Cãtoiu, I. (coord.),(2002), Cercetãri de Marketing (Marketing Researches), Uranus PH, Bucharest, Romania

Dibb S. and Wensley R, (2002), Segmentation analysis for industrial markets: Problems of integrating customer requirements into operations strategy, European Journal of Marketing, Vol. 36 Iss: 1/2, pp. $231-251$

Florescu C.,(1992), Marketing, Marketer PH, Bucharest, Romania

Hellman, K., (2005), Strategy-driven B2B promotions. The Journal of Business \& Industrial Marketing, 20(1), pp.4-11

Hetzel, P., (2004), Le Marketing Relationnel, Presses Universitaires de France, Paris, France

Hutt D. M. and Spech W. T., (2004), Business Marketing Management - A Strategic View of Industrial and Organizational Markets, Thomson South - Western PH, New York, USA

Ketchen Jr. D.J.,Thomas G. and Hult M., (2007), Toward greater integration of insights from organization theory and supply chain management, Journal of Operations Management. Vol. 25, Iss. 2, pp. $455-458$

Kotler, Ph. and Armstrong, G.,(2005), Principles of Marketing, $11^{\text {th }}$ Edition, Prentice House , New York, USA

Laiderman J., (2005), A structured approach to B2B segmentation, Journal of Database Marketing \& Customer Strategy Management, Vol. 13, pp.64-75

Lee R. P. and Grewal R., (2004), Strategic Responses to New Technologies and Their Impact on Firm Performance, Journal of Marketing, Vol. 68, No. 4., pp. 157-171

Möller, K. and Halinen, A.,(2000), Relationship Marketing Theory: Its Roots and Direction, Journal of Marketing Management, vol. 16, no. 1, pp. 29-54

Noir M., (1997), Réussir une campagne électorale: suivre l'exemple américain? Les Editions d'Organisations, Paris, France

Olteanu V., (2003), Management-marketing (Marketing Management), Ecomar PH, București, Romania

Palmer R., (2002), Managerial understanding of contemporary industrial marketing issues, Qualitative Market Research: An International Journal, Vol. 5 Iss: 2, pp.135 - 143

Porter, M. E., (2001), 'Competitive strategy', Teora PH, Bucharest, Romania

Rangan, V. K. and Shapiro B. P., (1995), Business marketing strategy : cases, concepts and applications ,Irwin PH, London, UK

Taylor A. D., (2003), Suplly chains: A Manager's Guide, Addison Wesley PH, London,UK

Tull Donald S. and Kahle Lynn R., (1990), Marketing management, Macmillan PH, New York, USA

Webster F. E. Jr., (1991), Industrial Marketing Strategy, 3rd Edition, John Wiley \&Sons Inc,PH, NewYork,USA 